\title{
Quantitative analysis of movement along an earthquake thrust scarp: a case study of a vertical exposure of the 1999 surface rupture of the Chelungpu fault at Wufeng, Western Taiwan
}

\author{
Jian-Cheng Lee ${ }^{\mathrm{a}, *}$, Charles Rubin ${ }^{\mathrm{b}}$, Karl Mueller ${ }^{\mathrm{c}}$, Yue-Gau Chen ${ }^{\mathrm{d}}$, Yu-Chang Chan ${ }^{\mathrm{a}}$, \\ Kerry Sieh ${ }^{\mathrm{e}}$, Hao-Tsu Chu ${ }^{\mathrm{f}}$, Wen-Shan Chen ${ }^{\mathrm{d}}$ \\ ${ }^{a}$ Institute of Earth Sciences, Academia Sinica, P.O. Box 1-55, Nankang, Taipei 115, Taiwan, ROC \\ ${ }^{\mathrm{b}}$ Department of Geological Sciences, Central Washington University, Ellensburg, WA, USA \\ ${ }^{\mathrm{c}}$ Department of Geology, University of Colorado, Boulder, CO, USA \\ ${ }^{\mathrm{d}}$ Department of Geosciences, National Taiwan University, Taipei, Taiwan, ROC \\ e Division of Geological and Planetary Science, MC 100-23, Caltech, Pasadena, CA, USA \\ ${ }^{\mathrm{f}}$ Central Geological Survey, P.O. Box 968, Taipei, Taiwan, ROC
}

Received 1 July 2002; revised 28 April 2003; accepted 28 April 2003

\begin{abstract}
A vertical exposure across the principal thrust scarp of the $1999 \mathrm{Mw} 7.6$ earthquake allows quantification of fault slip. The exposure is located on the active Chelungpu fault near Wufeng, along the range front of the fold-and-thrust belt in western Taiwan. The 1999 surface ruptures at the Wufeng site are characterized by a west-facing 2 to $3 \mathrm{~m}$ high principal thrust scarp and an east-facing lesser backthrust scarp. We mapped a $15 \mathrm{~m}-$ long, $5 \mathrm{~m}$-deep exposure across the principal thrust scarp and characterized complex deformation structures, which include a main basal thrust fault, a wedge thrust, and a pop-up anticlinal fold with two secondary opposing thrust faults. The vertical displacement across the principal thrust scarp is measured directly from the offsets of the same sedimentary horizons between the hangingwall and the footwall. The average vertical displacement is $2.2 \pm 0.1 \mathrm{~m}$, and the maximum displacement is $2.5 \mathrm{~m}$, at the crest of the small pop-up fold. Horizontal displacement estimates were determined using line- and area-balancing methods. With line-length methods we estimated a horizontal displacement of $3.3 \pm 0.3 \mathrm{~m}$ across the principal scarp for four sedimentary horizons. For area balancing, first we selected three horizontal soil/sand deposits with a total thickness of about $0.5 \mathrm{~m}$. The estimate yields an average horizontal displacement of $4.8 \pm 1.0 \mathrm{~m}$. Using these individual and relatively thin stratigraphic layers yielded significant standard deviations in displacement estimates as a result of thickness variations. Second, we used the $3 \mathrm{~m}-$ thick overbank soil/sand and the lower part of fluvial pebble/cobble to calculate a horizontal displacement of $2.6 \pm 0.2 \mathrm{~m}$ with the area-balancing technique. According to the geometry of the dip angle $\left(35-40^{\circ}\right)$ of the basal thrust, the line-length measurement and the $3 \mathrm{~m}$-thick package area balancing both provided reasonable results of horizontal displacement. By comparing the different deposits applied to the line-and area-balancing methods, we interpret that decoupling of deformation occurred between the lower fluvial gravels and the upper overbank sand and mud deposits. Due to lesser confining pressure at the surface, additional deformation occurred in the upper 1-2 $\mathrm{m}$ thick overbank deposits. This additional deformation yielded further vertical uplift of $0.3-0.5 \mathrm{~m}$ and horizontal displacement of $0.2-0.8 \mathrm{~m}$ around the core of the pop-up fold. Our work suggests that determination of slip across surface thrust ruptures varies as a function of the mechanical behavior of young late Quaternary deposits. (C) 2003 Elsevier Ltd. All rights reserved.
\end{abstract}

Keywords: Earthquake fault; Thrust; Chi-Chi earthquake; Balanced cross-section; Taiwan

\section{Introduction}

The destructive $1999 \mathrm{Mw} 7.6 \mathrm{Chi}-\mathrm{Chi}$ earthquake resulted from rupture along the Chelungpu fault at

\footnotetext{
* Corresponding author. Tel.: +886-2-2783-9910x413; fax: +886-22783-9871.

E-mail address: jclee@earth.sinica.edu.tw (J.-C. Lee).
}

a shallow crustal level (Chung and Shin, 1999; Ma et al., 1999; Kao and Chen, 2000) and produced surface rupture over a distance of $95 \mathrm{~km}$ (Central Geological Survey, 1999a,b; Fig. 1). The surface fault ruptures are characterized by nearly continuous thrust fault scarps with vertical throws as high as 5-8 m (Central Geological Survey, 1999a,b; Bilham and Yu, 2000; Kelson et al., 2000; Chen et al., 2001a, Lee et al., 2002). 



Fig. 1. (a) General geologic map (after Chinese Petroleum Corporation, 1974, 1982); (b) Geologic cross-section (after Mouthereau et al., 2001) of west-central Taiwan. Shortening is accommodated by a series of west-vergent thrusts. The Chi-Chi earthquake resulted principally from rupture along the Chelungpu fault; (c) Topographic map of the excavation site. Contour interval is $10 \mathrm{~m}$.

The horizontal components of the surface scarp deformation from the earthquake increased from south to north, ranging from 2 to $5 \mathrm{~m}$ (Central Geological Survey, 1999b). These values are less than the observed near-field GPS measurements of the coseismic horizontal displacements (Central Geological Survey, 1999b; Yang et al., 2000; Yu et al., 2001), which reveal horizontal displacements of $5-8 \mathrm{~m}$ across the Chelungpu fault.
Strain partitioning of thrust faulting along the principal scarp and strike-slip deformation distributed in the hangingwall has been proposed to explain the discrepancy of horizontal displacements between geodetic and geologic data (Angelier et al., 2003 a,b). In order to construct the geometry of the 1999 surface fault and understand the kinematics of surface faulting, it is thus important to quantify the vertical and horizontal 
displacements on site. For example, fault slip vectors were determined at bedrock outcrops to quantify the magnitude of the deformation (Lee et al., 2002). The amount of surface deformation also was estimated by simple geometric restorations of the surface markers (Angelier et al., 2000; Kelson et al., 2001; Lee et al., 2002). In general, the vertical displacements could usually be directly measured, however, the horizontal components of fault slip across the thrust fault scarps were more difficult to determine. For example, onlapping strata and missing or eroded correlative hangingwall strata occurred commonly in the thrust fault scarps. This often leads to underestimation of the amount of horizontal displacement along the surface faults and overestimation of the dip angles of the fault at the near-surface level. It is therefore important to carefully determine the horizontal component of slip for precise reconstruction of the geometry and kinematics of the Chelungpu thrust fault.

A vertical exposure across the Chi-Chi surface scarp in the Wufeng area (Fig. 2) shows the complex deformation structures beneath the typical surface thrust scarps along the Chelungpu fault. The Wufeng excavation exhibited exceptionally detailed deformation structures and thus provides an excellent opportunity to quantify the earthquake surface fault slip and also to characterize the deformation behavior in the near surface level. Our previous paper (Lee et al., 2001) documented the overall structural characteristics and evidence of a prior earthquake. In this paper, we quantify the fault movement using line- and area-balancing methods. We show that different displacements occur at different structural levels, perhaps due to the response of the deformed materials to a decrease in confining pressure near the surface.

\section{Main scarp of the Wufeng excavation}

The Wufeng exposure is located on the Wufeng-Nantou segment (Tsaotun segment of Chen et al., 2001,2002) of the 1999 rupture of the Chelungpu thrust fault (Fig. 1). This $30 \mathrm{~km}$-long, N-S trending segment represents the longest segment of the 1999 rupture. It exhibited a nearly continuous, sinuous thrust scarp 2-3 m high that closely followed the previously mapped trace of the Chelungpu fault. The 1999 surface rupture exposed in the Wufeng excavation is located about $100 \mathrm{~m}$ west of the mountain front, which is a major morphologic and geologic boundary between the Mio-Pliocene foothills to the east and the Quaternary coastal plain and tablelands to the west (Fig. 1). The Wufeng trench wall exposure consists of Holocene alluvium composed of fluvial and overbank deposits derived from a nearby major river, the Wu Chi (Fig. 1). Based on a nearby industry borehole (Chou, 1971) and paleoseismic excavations (Chen et al., 2001b), Holocene alluvium and Quaternary fluvial deposits, which overlie the Pliocene bedrock, are about $8-10 \mathrm{~m}$ thick in the hangingwall and about $2000 \mathrm{~m}$ thick in the footwall.

The excavation at the Wufeng site was carried out in March 2000, six months after the earthquake when the earthquake scarps remained almost complete and little erosion had occurred on surface ruptures. We used a track hoe to excavate a $60 \mathrm{~m}$-long and 3-5 m-deep vertical exposure across the zone surface ruptures provided in the 1999 earthquake. The trend of the excavation $\left(\mathrm{N} 85^{\circ} \mathrm{E}\right)$ is nearly perpendicular to the surface fault trend $\left(\mathrm{N} 10^{\circ}-20^{\circ} \mathrm{E}\right)$ and is almost parallel to the slip vector of $\mathrm{N} 81^{\circ} \mathrm{W}$ determined by Lee et al. (2003). We mapped the stratigraphy and structures in the exposure with the control of a horizontal level at an interval of $1 \mathrm{~m}$.

The principal scarp of the Wufeng excavation was a $2.5 \mathrm{~m}$ west-facing scarp. The vertical exposure displays two distinct sedimentary deposits: a lower cobbly gravel fluvial deposit and an upper overbank sand deposit capped by a cultivated soil (Figs. 2 and 3). The stratigraphic contacts, especially the ones between gravel-sand and sand-soil, are generally linear and easily distinguished in the field. At least three to four fining upward sequences are observed in the overbank sand deposits. Radiocarbon dating of charcoal samples in the overbank deposits (mud layers of Unit 3 and Unit 4) indicated a young depositional age of less than $200 \mathrm{yr}$ BP (Fig. 3). Detrital charcoal was not recovered from the lower gravels. Based on the lack of weathering and soil development, there was no significant hiatus between the upper overbank deposits and the lower fluvial gravels. Because the fluvial and overbank sediments were deposited on an alluvial fan with a very gentle gradient, the original dip of the strata along the $\mathrm{E}-\mathrm{W}$ trending excavation was nearly flat $\left(1-2^{\circ} \mathrm{NW}\right)$. Thus the strata must have been essentially horizontal before the 1999 earthquake. The flat-lying upper $1-1.2 \mathrm{~m}$ layers (Units 1-3 in Fig. 2(b)) maintain a uniform thickness across the thrust scarp. However, the underlying layers showed a different depositional facies across the scarp (Unit 8 in the footwall against Units $4-6$ in the hangingwall). Because of the presence of different facies across the scarp, careful attention is necessary for the area-balancing analysis.

The deformation structures across the principal scarp were characterized by a major east-dipping basal thrust and several structures in the hangingwall, including a breakthrough wedge thrust, and a pop-up anticlinal fold bounded by two opposing secondary thrusts (Fig. 2(b)). Restoration of the deformation across the principal scarp suggests a complex structural evolution (Lee et al., 2001).

\section{Fault kinematics}

Here we present a quantitative analysis of 1999 surface fault movement at the Wufeng site. The vertical 

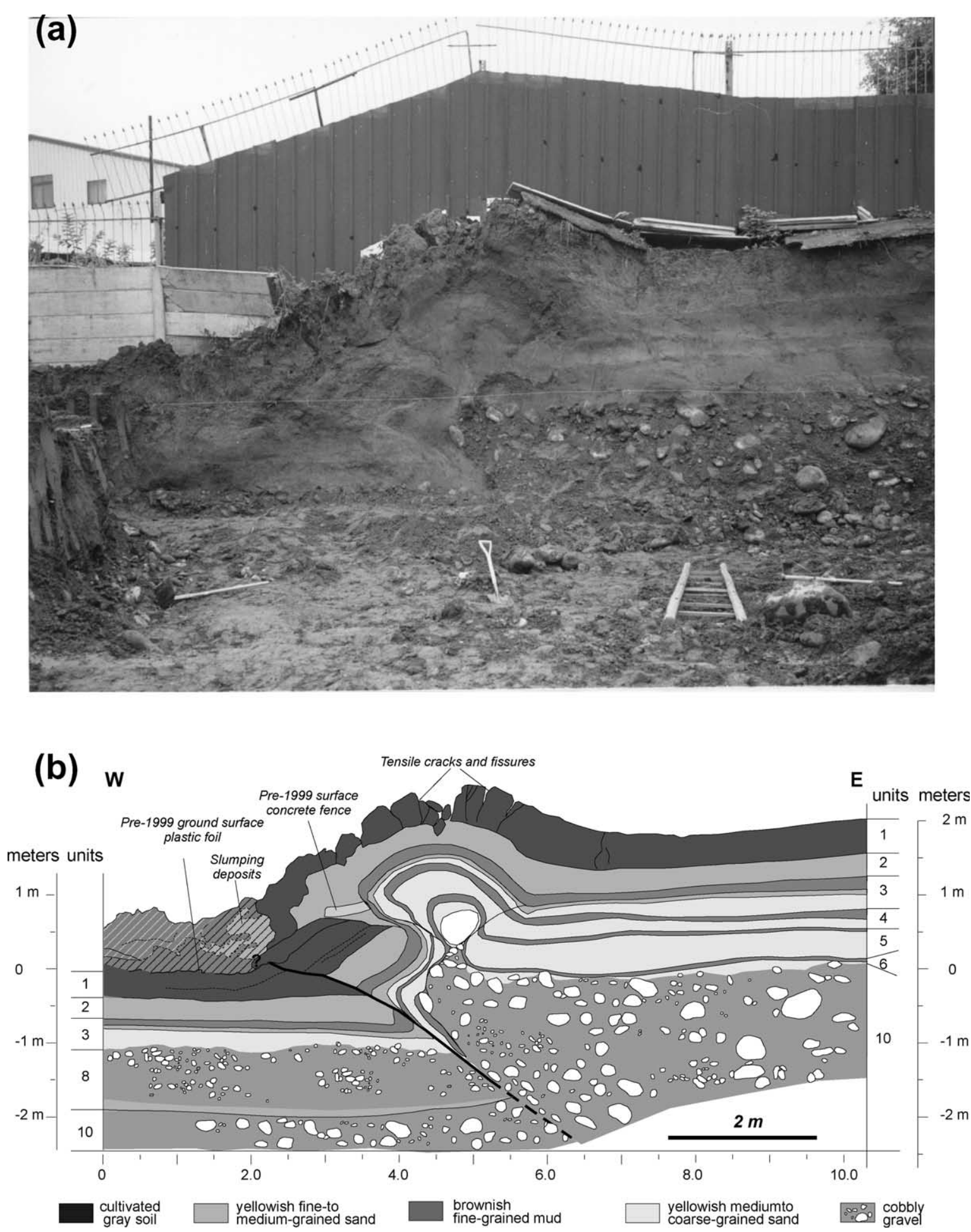

Fig. 2. (a) Vertical exposure of the principal rupture; (b) Map of trench wall showing geologic contacts and faults (after Lee et al., 2001). The deformation is characterized by a basal fault and a pop-up anticlinal fold with two opposing thrusts.

displacement across the thrust scarp was obtained by measuring the difference of heights between the hangingwall and the footwall. A maximum vertical offset of $2.5 \mathrm{~m}$ is obtained due to uplift of the pop-up fold immediately across the surface fault. Because the anticlinal pop-up fold on the thrust fault scarp is a result of local squeeze-up within the fault zone, we use the average height outside of the fault zone on the hangingwall side to estimate representative vertical displacement. We measured the difference in elevation of the beds between points across the fault zone. The values range from 2.1 to $2.3 \mathrm{~m}$ (Table 1), and average $2.2 \pm 0.1 \mathrm{~m}$. For the horizontal component, we applied 


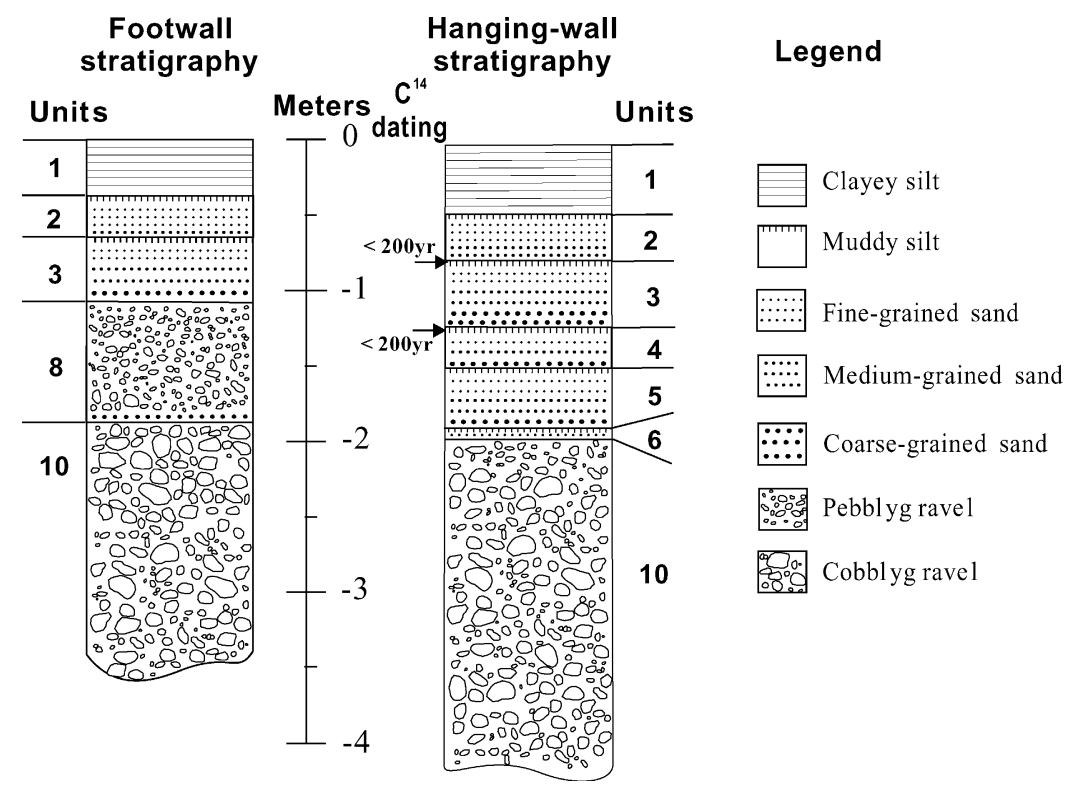

Fig. 3. Generalized stratigraphy of sedimentary deposits in excavation. Strata consist of fluvial gravels and fining upward sequences of overbank sands. Vertical hatch marks on muddy silt is an incipient soil profile. Note difference in sequences on footwall versus hanging-wall.

two different restoration techniques: line-balancing measurement and area-balancing calculation. These two common balancing techniques have been used widely to balance geological cross-sections at regional scales (e.g. Woodward et al., 1989).

\subsection{Analysis of line-length measurement}

We first used the line-length balancing method along the depositional contacts to estimate the amount of the horizontal displacement (Fig. 4). Five depositional contacts have been traced, including the top edge of Unit 1 (red line), the contact between Unit 1 and Unit 2 (yellow line), the contact between Unit 2 and Unit 3 (green line), the bottom of Unit 3 (blue line), and the top of Unit 10 (purple line). The line lengths for each horizon of contact were measured. Each horizon is comprised of several line segments, which were separated by faults and tensile fissures (Fig. 4). Since the uppermost horizon (red line) yields a much smaller horizontal displacement of $2.3 \mathrm{~m}$, due to erosion, the horizon was omitted in our linebalancing estimate.
For each horizon, we measured all the small line segments and summed them up. From top to bottom, the summed lengths are 13.2,13.2, 13.8, and $13.0 \mathrm{~m}$ for the yellow, green, blue, and purple lines, respectively. The average summed lengths is $13.3 \pm 0.3 \mathrm{~m}$ (Table 1). Comparison of the average summed length of $13.3 \pm 0.3 \mathrm{~m}$ with the post-faulting length of the profile of $10.0 \mathrm{~m}$ directly measured in the exposure yielded a difference in line length of $3.3 \pm 0.3 \mathrm{~m}$. This is a measure of the amount of horizontal displacement parallel to the exposure.

\subsection{Analysis of area-balancing technique}

Area-balancing calculation is a complementary method for estimating the amounts of horizontal displacement across the main scarp of the Wufeng exposure. The area of an individual layer deformed during the earthquake would be the same prior to the earthquake, assuming there was no significant change in density of these young sediments. Individual layers can be restored to a rectangular shape, with the same thickness as present, assuming no significant pure

Table 1

Amounts of 1999 fault movement derived from the line-length technique along the four depositional contacts in the Wufeng excavation

\begin{tabular}{|c|c|c|c|c|c|}
\hline & Calculated length (m) & Horizontal displacement (m) & Vertical offset (m) & Calculated total slip (m) & Derived thrust dip-angle $\left({ }^{\circ}\right)$ \\
\hline Yellow line & 13.2 & 3.2 & 2.2 & - & - \\
\hline Green line & 13.2 & 3.2 & 2.1 & - & - \\
\hline Blue line & 13.8 & 3.8 & 2.1 & - & - \\
\hline Purple line & 13.0 & 3.0 & 2.3 & - & - \\
\hline Average & $13.3 \pm 0.3$ & $3.3 \pm 0.3$ & $2.2 \pm 0.1$ & $4.0 \pm 0.2$ & $34 \pm 3$ \\
\hline
\end{tabular}

Horizontal displacement is obtained by comparing the calculated length for each line to the measured post-earthquake length of $10.0 \mathrm{~m}$. 


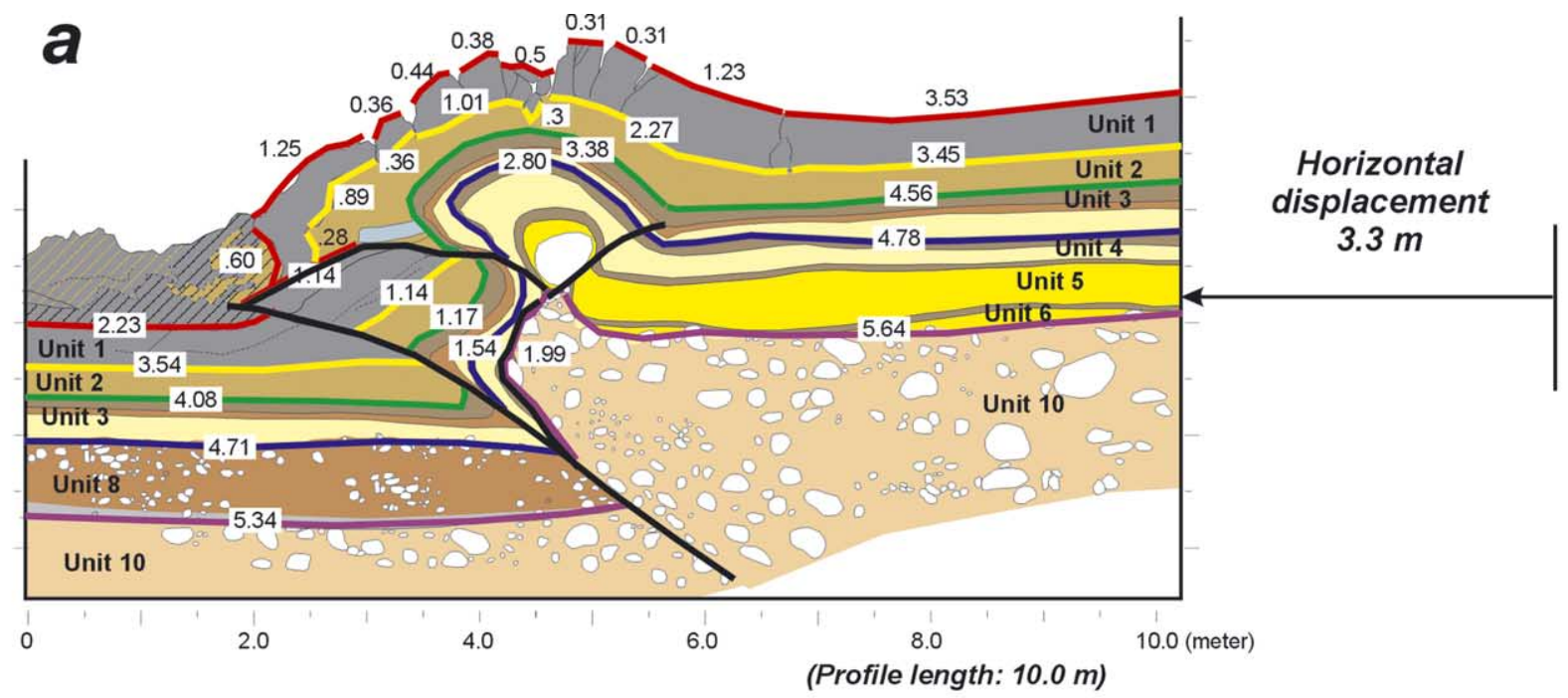

b

Average length of undeformed profile: 13.3 meters

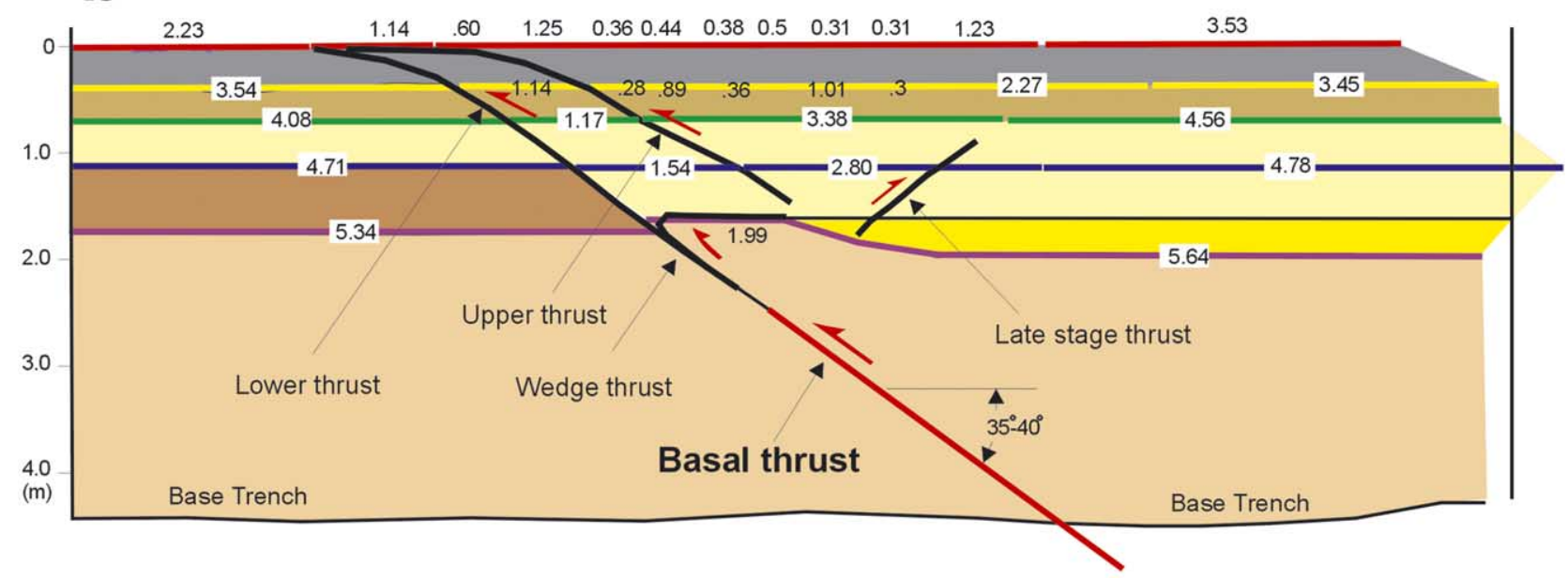

Fig. 4. Restoration of the scarp and pop-up anticline based on measurement of line-lengths. Five depositional contacts were measured. Upper figure shows line lengths of each segment of the depositional contacts. The numbers on the depositional contacts indicate the length in meters for each segment; segments are separated by faults or tensile cracks. The current length of the profile, $10.0 \mathrm{~m}$, is measured directly from the edges of the cross section. Horizontal and vertical components of shortening are shown in Table 1. Lower figure is a stratigraphic separation diagram illustrating fault trajectories.

shear occurred during the earthquake. The length of this restored rectangle is thus equal to the original length of the layer. In practice, we first measured the amount of the area for a specific layer at the present state. We then calculate its original restored length by dividing the area by the thickness of this specific layer. By comparing the restored original length to the present length directly measured in the excavation, we thus obtain the horizontal displacement parallel to the exposure for this layer.

We first choose three layers in the Wufeng excavation for area balancing: (1) the yellowish fine- to medium-grained sand (Unit 2) under the uppermost paddy clay, (2) the underlying brownish fine-grained mud (upper Unit 3), and (3) the yellowish fine- to medium-grained sand layer (middle Unit 3). The uppermost paddy layer was not chosen because it is disturbed by spalling at the scarp face. The reasons for choosing these three layers are because that they are relatively uniform in thickness, were undisturbed by spalling at the scarp face, and both the upper and lower contacts of the units are well defined and presumably correlative across the profile.

The calculations and measurements of the areas and the thickness of layers were based on the digitized excavation $\log$. The thickness for each layer was measured 6 to 8 times at the different locations throughout the excavation but outside the pop-up fold zone to avoid localized variation in internal strain. The average thickness of these layers with standard errors is listed in Table 2.

The measured areas and thickness yielded horizontal displacements of $4.6 \pm 1.6,4.9 \pm 3.2$, and $5.5 \pm 1.9 \mathrm{~m}$ for the three individual layers, respectively, (Table 2 and Fig. 5). The relatively large standard deviations derive mainly from (1) the disturbance by spalling at the scarp face, which is especially the case for the uppermost layer, 
Table 2

Amounts of 1999 fault movement derived from area-balancing technique in the Wufeng excavation

\begin{tabular}{|c|c|c|c|c|c|c|c|}
\hline & $\begin{array}{l}\text { Measured } \\
\text { Area }\left(\mathrm{m}^{2}\right)\end{array}$ & Thickness (m) & $\begin{array}{l}\text { Calculated } \\
\text { length (m) }\end{array}$ & $\begin{array}{l}\text { Horizontal } \\
\text { displacement (m) }\end{array}$ & $\begin{array}{l}\text { Vertical } \\
\text { offset }(m)\end{array}$ & $\begin{array}{l}\text { Calculated } \\
\text { total slip (m) }\end{array}$ & $\begin{array}{l}\text { Derived thrust } \\
\text { dip-angle }\left({ }^{\circ}\right)\end{array}$ \\
\hline Unit 2 & 4.40 & $0.30 \pm 0.1$ & $14.6 \pm 1.6$ & $4.6 \pm 1.6$ & 2.22 & - & - \\
\hline Upper Unit 3 & 1.63 & $0.11 \pm 0.1$ & $14.9 \pm 3.2$ & $4.9 \pm 3.2$ & 2.14 & - & - \\
\hline Middle Unit 3 & 0.87 & $0.06 \pm 0.1$ & $15.5 \pm 1.9$ & $5.5 \pm 1.9$ & 2.14 & - & - \\
\hline Three layers assemblage & 6.90 & $0.46 \pm 0.1$ & $14.8 \pm 1.0$ & $4.8 \pm 1.0$ & $2.2 \pm 0.1$ & $5.3 \pm 1.0$ & $24 \pm 4$ \\
\hline Complete $3 \mathrm{~m}$-thick package & 34.77 & $2.7 \pm 0.1$ & $12.6 \pm 0.2$ & $2.6 \pm 0.2$ & $2.2 \pm 0.1$ & $3.4 \pm 0.2$ & $39 \pm 2$ \\
\hline
\end{tabular}

Two different assemblages of units were assessed: the upper deposits with rather uniform thickness across the scarp (Unit 2, upper Unit 3, and middle Unit 3 ) and the complete $3 \mathrm{~m}$ thick package of the excavation.

(2) the resolution of the upper and lower boundaries of individual layers, and particularly (3) the variation in thickness for individual layers. The results indicate that the layer thickness is sensitive for estimating the horizontal displacement. Even for these three units with relatively uniform thickness, uncertainties are large. In order to reduce the thickness variations, an alternative method uses all three units as a package for area-balancing calculation. We used the same techniques described above to measure the area and the thickness for this three-unit package (Unit 2, upper Unit 3, and middle Unit 3) to obtain the original length before the 1999 rupture. Balancing these three units together yields a horizontal displacement of $4.8 \pm 1.0 \mathrm{~m}$ (Fig. 5). This result, although yielding a smaller standard error, still contains a significant standard deviation.

In order to minimize the standard deviation and the effect of layer thickness, the relatively thick sedimentary package consisting of the entire upper $3 \mathrm{~m}$ of deposits

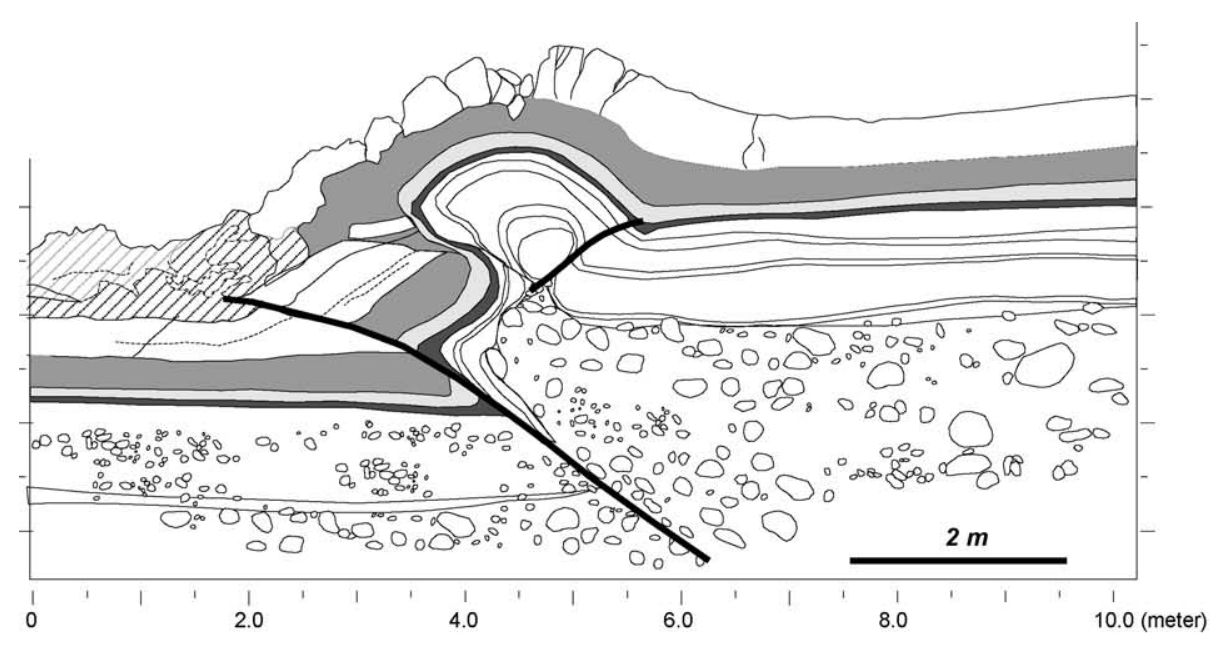

(Profile length: $10.0 \mathrm{~m}$ )

Horizontal shortening $4.8 \mathrm{~m}$

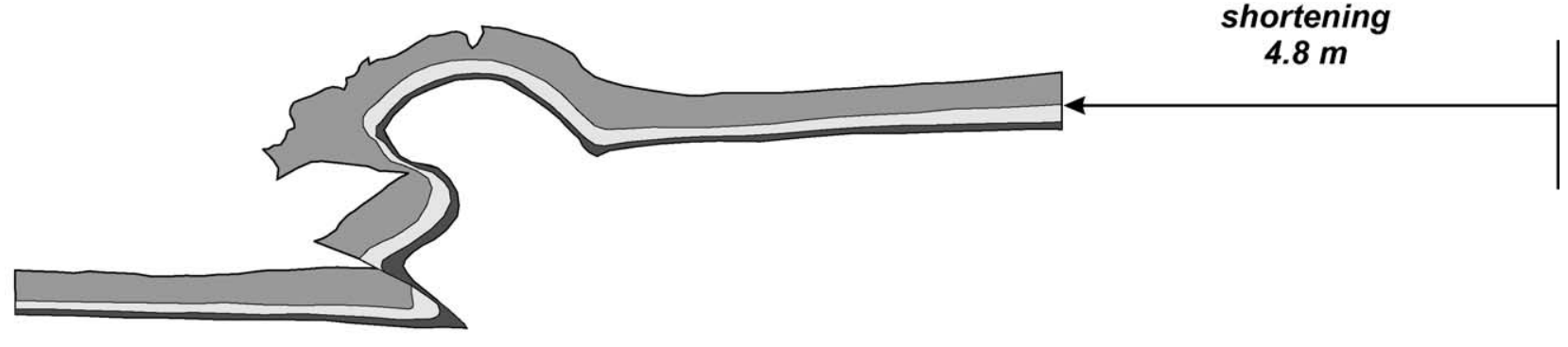

Retro-deformed profile length: $14.8 \mathrm{~m}$

Fig. 5. Restoration of the scarp and pop-up anticline based on area-balancing technique. Three sedimentary layers have been chosen for retro-deformation: the yellowish fine- to medium-grained sand (Unit 2), the underlying brownish fine-grained mud (upper Unit 3), and the yellowish fine- to medium-grained sand layer (middle Unit 3). The average thickness of the three layers is $0.46 \pm 0.1 \mathrm{~m}$, and the area, $6.90 \mathrm{~m}^{2}$, together yield $4.8 \pm 1.0 \mathrm{~m}$ of horizontal displacement. Results in Table 2 . 


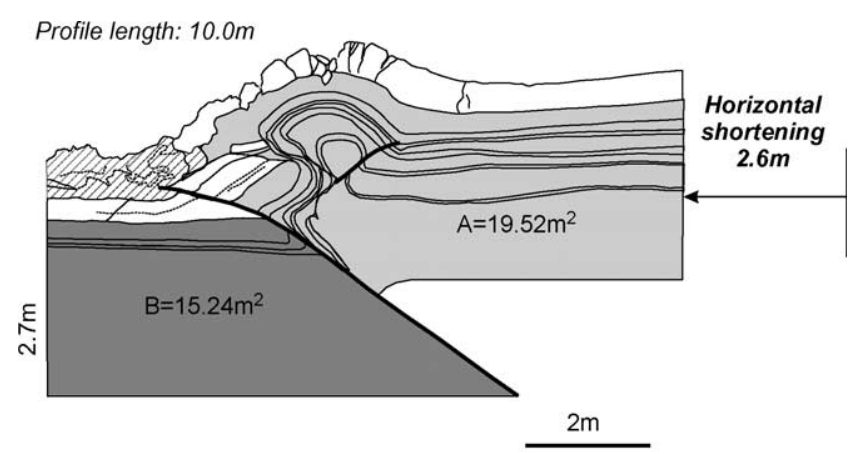

Restored profile length: $12.6 \mathrm{~m}$

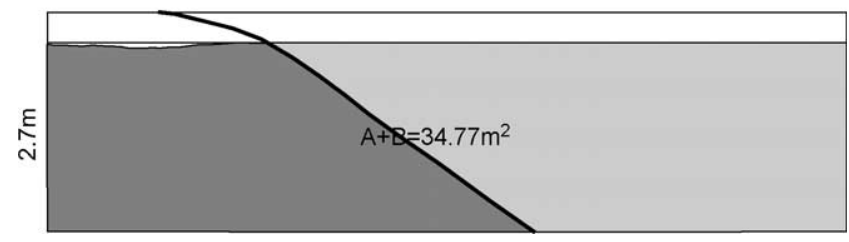

Fig. 6. Restoration of the scarp and pop-up anticline based on areabalancing technique. The complete package (except the uppermost paddy clay) was used for retro-deformation. See Table 2 for results.

except the uppermost paddy clay was used in subsequent area-balancing restorations (Fig. 6). Although this package includes different sedimentary layers, such as different depositional facies across the main scarp, all the different sedimentary units, including the overbank soil, sands and fluvial conglomerates are mostly horizontal. The top margin of the entire package is quite planar (i.e. the boundary between Unit 1 and Unit 2). The bottom of the sedimentary package was defined as the horizon in the gravels at the depth of $3.0 \mathrm{~m}$ near the base of the excavation. Because the surface was horizontal and all the strata in the excavation also appeared to be flat-lying outside the fault zone, it is reasonable to use the same thickness across the scarp as the thickness of the entire package, in spite of the presence of different facies across the fault. We traced imbricate pebbles along the bottom of the $3 \mathrm{~m}$-thick package, which are arranged to form a nearly horizontal line. Although there was a narrow sheared zone of $5-10 \mathrm{~cm}$ wide along the basal thrust fault, the imbricate pebbles also remain essentially horizontal in the gravel deposit. As a result, it is reasonable to restore these strata by area balancing, which assumes the sedimentary package was horizontal prior to deformation (Fig. 6(b)). We obtained a length for the restored profile of $12.6 \pm 0.3 \mathrm{~m}$, which yields the horizontal displacement $2.6 \pm 0.3 \mathrm{~m}$ across the main scarp (Fig. 6; Table 2).

The smaller standard deviation of the $3 \mathrm{~m}$-thick package ( $0.3 \mathrm{~m}$ compared to $1.0 \mathrm{~m}$ from three upper sand/mud units) suggests that small changes in thickness of individual layers are accommodated by thinning or thickening of adjacent layers within the entire package. We thus prefer using the entire package of deposits in the exposure for the areabalancing retro-deformation calculation, because of its greater accuracy. We consider $2.6 \mathrm{~m}$ to be a representative amount of horizontal displacement across the 1999 surface fault in the exposure. However, differential deformation, including horizontal and vertical displacements, might have occurred within individual layers contained in the entire package.

\section{Discussion and conclusions}

\subsection{Different results for line- and area-balancing methods}

Different results of horizontal displacements have been obtained between the line-balancing and area-balancing methods. Area balancing the three-layer $0.5 \mathrm{~m}$ overbank package yields $4.8 \pm 1.0 \mathrm{~m}$ of horizontal displacement. Alternatively, balancing the complete $3 \mathrm{~m}$-thick package of deposits yields about $2.6 \pm 0.3 \mathrm{~m}$ of horizontal displacement. The line balancing, on the other hand, yields $3.3 \pm 0.3 \mathrm{~m}$ of horizontal displacement. Because of large standard deviation, we rejected the $4.8 \mathrm{~m}$ of horizontal displacement from balancing the three-layer package. It was still not clear which method, line or area balancing, yielded a more accurate result. The $2 \mathrm{D}$ area-balancing technique has an additional dimensional constraint in comparison to the line-balancing technique. However, the 2D method may be affected by unresolved large variation in thickness in highly strained parts of the structure. Therefore, we consider horizontal displacement to range between 2.6 and $3.3 \mathrm{~m}$.

For the line-balancing method, the uncertainties stem mainly from the complex deformation near the main fault zone, such as the overlapping structures and the presence of ductile deformation. In particular, stretching and thinning of the sedimentary layers can be clearly observed around the core of the pop-up fold, especially for the upper soft overbank sand and mud deposits. The stretching effect yields an overestimation of the actual amount of shortening across the thrust scarp. Alternatively, eroded or onlapped strata yield an underestimation of shortening amounts. The stretched layers around the core of the small pop-up fold suggest overestimation of horizontal displacement from line-length measurement. For example, the line-measurement of the blue line, which was traced along a relatively soft mud layer (contact between Units 3 and 4) in the hangingwall, shows a relatively larger horizontal displacement of $3.8 \mathrm{~m}$ (Table 1 and Fig. 4). Because the four horizons used in the line balancing were mostly measured within the upper soft deposits, we speculate that the average $3.3 \mathrm{~m}$ displacement may define deformation recovered by the overbank deposits. The underlying gravels might have lesser horizontal displacement because of their more competent rheology. However, line-balancing method should not be applied to the gravels due to a lack of clearly defined internal bedding surfaces. If so, this may imply that strain decoupling occurred at different structural levels between the upper soft overbank deposits and the lower fluvial gravels. 
The uncertainties for area-balancing method are derived mostly from our ability to measure the thickness of individual layers, and in particular, the primary depositional variation in thickness of these layers. Another possible source of uncertainty is a stress-induced change in density of sedimentary layers near the major zone of deformation. Density changes due to local compaction and stretching, especially within the deformation zone across the thrust scarp where several reverse faults and folds developed in a complex pattern, are poorly constrained. Because detailed quantitative analysis of such uncertainty remains difficult, we compare the results between different balancing methods, which were applied to different layers of deposits, in order to determine the discrepancy in deformation between deposits of different compositions that may respond differently to strain.

The large horizontal displacement of $4.8 \mathrm{~m}$ determined from the three-layer area-balancing method is due to the effects of local stretching and perhaps changes in bulk density. The $4.8 \mathrm{~m}$ displacement was defined from the sand/mud overbank deposits may have lower bulk densities in the core of the pop-up fold zone. If these deposits did indeed experience a decrease in bulk density due to the earthquake, area balancing would yield a larger horizontal displacement, assuming the thickness of these strata were unchanged. Alternatively, an increase in bulk density may have occurred in the lower fluvial gravels, where pebbles and cobbles in the gravels were more tightly packed near the basal fault. The $2.6 \mathrm{~m}$ horizontal displacement from area-balancing calculation of the complete $3 \mathrm{~m}$-thick package has the least uncertainty among the area-balancing estimates and we consider it to be the most representative for the following reasons: (1) it has a smaller amount of thickness variation relative to its greater total thickness; (2) different density changes at the different deposits between the upper overbank and the lower gravels may have compensated each other.

\subsection{Comparison with observed fault dip angle}

The representative dip angle of the main fault is easily observed in the lower part of the excavation. A dip angle of about $35-40^{\circ}$ is directly measured from the exposure. We use the observed dip angle as a basis of comparison with the calculated dip angles, derived from the ratio of the measured vertical offset to the calculated horizontal displacement. The ratio of the vertical displacement $(2.2 \pm 0.1 \mathrm{~m})$ to the horizontal displacement from the line-balancing method ( $3.3 \mathrm{~m}$ ) yields a $34^{\circ}$ dip for the basal fault plane below the excavation. The entire $3 \mathrm{~m}$-thick package area-balancing technique yielded a $40^{\circ}$ dip angle. This simple calculation indicates that the representative horizontal displacement of the Wufeng excavation ranges from 2.6 to $3.3 \mathrm{~m}$ and that both line-length measurement and $3 \mathrm{~m}$-thick package area balancing provided reasonable results. The calculated $34^{\circ}$ dip angle from the line-balancing method represents the lower limit of the observed dip, and the calculated $40^{\circ}$ dip angle from the area-balancing method the upper limit. We interpret the different calculated horizontal displacements as a result of differential internal strain that may have occurred between the upper and lower deposits in the exposure.

\subsection{Decoupling of deformation at different structural level}

The deformation zone in the hangingwall of the excavation profile is characterized by two distinct structural domains (Fig. 7): (1) a complicated structural domain with several faults and folds in its upper part and in the pop-up fold deformation zone and (2) a simple structural domain with one basal thrust in the lower portion and the rest of

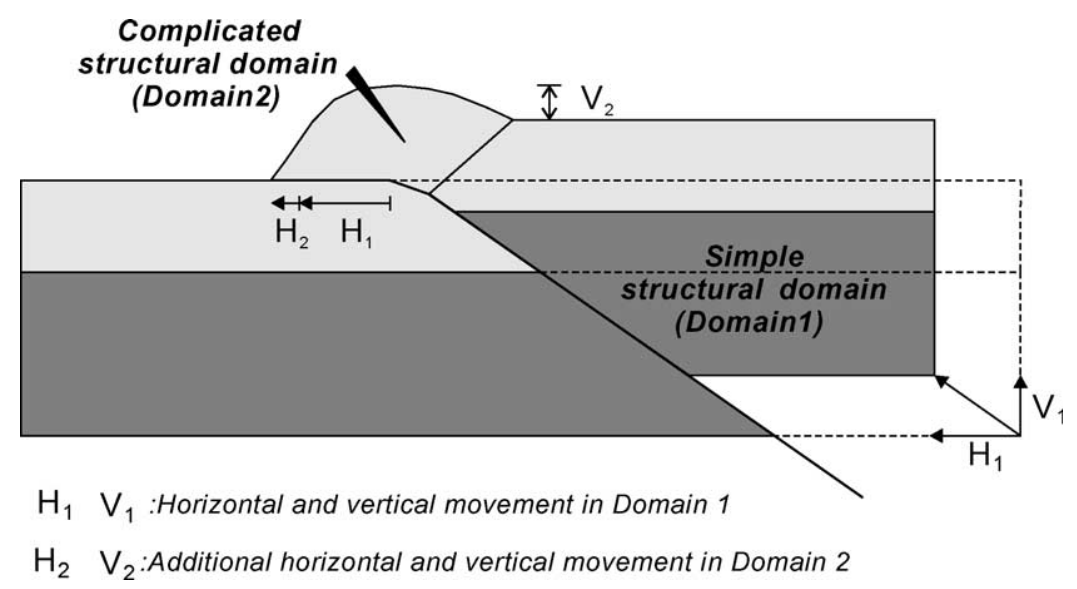

Fig. 7. Schematic profile illustrating decoupling of deformation occurred between the lower simple structural domain (fluvial gravels) and the upper complicated structural domain (overbank deposits). In the simple structural domain, deformation mainly occurred as slippage on the basal thrust. Slip can be decomposed into a vertical component $V_{1}$ and a horizontal component $H_{1}$. Due to lesser confining pressure near the surface, the upper structural domain experienced additional deformation accommodated by the wedge thrust fault and pop-up fold. This additional deformation can be decomposed into a vertical uplift $V_{2}$ and a horizontal displacement $\mathrm{H}_{2}$. 
the hangingwall to the east of the pop-up fold. The two domains are decoupled. Slip along the main thrust in the lower part of the excavation produces a vertical uplift of $V_{1}$ and a horizontal displacement of $H_{1}$ in the lower part (Fig. 7). The complex deformation in the upper part can be simplified as one lower angle thrust and backthrust. Deformation thus included a vertical displacement of $V_{2}$ and a horizontal displacement of $\mathrm{H}_{2}$ in the upper part in addition to deformation in the lower part. The additional horizontal displacement contributed by pop-up fold deformation $\left(H_{2}\right)$ in the upper part equals the total horizontal displacement $\left(H_{1}+H_{2}\right)$ minus the displacement of the lower part $\left(H_{1}\right)$.

Field observations indicate that the additional deformation is concentrated on the upper soft overbank sand and mud layers around the core of the pop-up fold. The amount of the additional vertical displacement $\left(V_{2}\right)$ in the pop-up is about $0.3-0.5 \mathrm{~m}$, which is obtained from direct measurement. We suggest that the large horizontal displacements derived from line-length technique based on the layers in the upper soft deposits are due to weaker mechanical behavior of the upper sand/mud compared to that of the lower gravel deposits. There is about $0.2-0.8 \mathrm{~m}$ difference of horizontal displacement between the calculated values from the upper and lower deposits. The difference of $0.2-0.8 \mathrm{~m}$ reflects the amount of the horizontal component of the additional deformation that occurred around the core of pop-up.

The line-length measurement thus yields a larger horizontal displacement of $3.3 \mathrm{~m}$. This is because the linelength method used depositional contacts in the upper soft overbank sand and mud layers that apparently absorbed more deformation perhaps due to different confining pressure. Alternatively, the gravels in the lower part of the exposure exhibit a stronger mechanical character that yields a smaller horizontal displacement. Area balancing the entire $3 \mathrm{~m}$-thick package yields a smaller horizontal displacement of $2.6 \mathrm{~m}$, because it uses the upper and lower sedimentary deposits.

In summary, the amounts of vertical and horizontal displacements depend on the mechanical behavior of materials. Due to low confining pressure at the ground surface, the upper 1-2 m-thick overbank sand and mud layers at the Wufeng exposure experienced additional vertical displacement of $0.3-0.5 \mathrm{~m}$ and horizontal displacement of $0.2-0.8 \mathrm{~m}$. Future studies thus need to consider the material properties along the earthquake fault near the ground surface.

\section{Acknowledgements}

This study was a cooperative Taiwan-American program and was supported by Institute of Earth Sciences, Academia Sinica, National Taiwan University, Central
Geological Survey, and National Science Council grants NSC90-2119-M001-003 and NSC91-2119-M001-027. Helpful reviews and comments by Keith Kelson and an anonymous reviewer greatly improved the manuscript. We would like to thank Robert Yeats for his help with the excavation work and Jacob Chu for editing the paper. This is a contribution of the Institute of Earth Sciences, Academia Sinica, IESAS842.

\section{References}

Angelier, J., Chu, H.T., Lee, J.C., Hu, J.C., Mouthereau, F., Lu, C.Y., Deffontaines, B., Lallemand, S., Tsai, Y.B., Chow, J.D., Bureau, D., 2000. Geological knowledge and seismic risk mitigation: insights from the Chi-Chi earthquake, Taiwan. Inter Workshop on annual commemoration of Chi-Chi earthquake, Taipei, pp.13-24.

Angelier, J., Lee, J.C., Chu, H.T., Hu, J.C., 2003a. Reconstruction of fault slip of the September 21st, 1999, Taiwan earthquake in the asphalted surface of a car park and co-seismic slip partitioning, Journal of Structural Geology 25(3) 345-350.

Angelier, J., Lee, J.C., Hu, J.C., Chu, H.T., 2003b. Three-dimensional deformation along the rupture trace of the September 21st,1999, Taiwan earthquake: a case study in the Kuangfu school, Journal of Structural Geology, 25(3), 351-370.

Bilham, R., Yu, T.T., 2000. The morphology of thrust faulting in the 21 September 1999, Chi-Chi, Taiwan earthquake. Journal of Asian Earth Sciences 18, 351-367.

Central Geological Survey, 1999a. Map of surface ruptures along the Chelungpu fault during the Chi-Chi earthquake, Taiwan, Central Geological Survey, 1:25,000 Central Geological Survey, MOEA, scale 1: 25,000.

Central Geological Survey, 1999b. Report of the geological survey of the 1999 Chi-Chi earthquake (in Chinese): Central Geological Survey.

Chen, Y.G., Chen, W.S., Lee, J.C., Lee, Y.H., Lee, C.T., Chang, H.C., Lo, C.H., 2001a. Surface rupture of $1999 \mathrm{Chi}-\mathrm{Chi}$ earthquake yields insights on active tectonics of central Taiwan. Bulletin of Seismological Society of America 91(5), 977-985.

Chen, W.S., Chen, Y.G., Chang, H.C., Lee, Y.H., Lee, J.C., 2001 b. Paleoseismic study of the Chelungpu fault in the Wanfung area. Western Pacific Earth Sciences 1(4), 499-506.

Chen, Y.G., Chen, W.S., Wang, Y., Lo, P.W., Lee, J.C., Liu, T.K., 2002. Geomorphic evidence for prior earthquakes: Lessons from the 1999 Chichi earthquake in central Taiwan, Geology 30(2) 171-174.

Chinese Petroleum Corporation, 1974. Geological map of Miaoli, scale 1:100,000. Chinese Petrol. Corporation, scale 1:100,000.

Chinese Petroleum Corporation, 1982. Geological map of Taichung, scale 1:100,000. Chinese Petrol. Corporation, scale 1:100,000.

Chou, J.T., 1971. A sedimentologic and paleogeographic study of the neogene formations in the Taichung region, Western Taiwan. Petroleum Geology of Taiwan 9, 43-66.

Chung, J.K., Shin, T.C., 1999. Implication of the rupture process from the displacement distribution of strong ground motions recorded during the 21 September 1999 Chi-Chi, Taiwan earthquake. Journal of Terrestrial Atmospheric and Oceanic Sciences 10(4), 777-786.

Kao, H., Chen, W.-P., 2000. The Chi-Chi earthquake sequence: active outof-sequence thrust faulting in Taiwan. Science 288, 2346-2349.

Kelson, K.I., Kang, K.H., Page, W.D., Lee, C.T., Cluff, L.S., 2000. Styles of deformation along the Chelungpu fault resulting from the 1999 Chi-Chi earthquake. EOS Transaction American Geophysical Union 81(48), F883.

Kelson, K.I., Kang, K.-H., Page, W.D., Lee, C.-T., Cluff, L.S., 2001. Representative styles of deformation along the Chelungpu fault from 
the 1999 Chi-Chi (Taiwan) earthquake: geomorphic characteristics and responses of man-made structures. Bulletin of Seismological Society of America 91(5), 930-952.

Lee, J.C., Chen, Y.G., Sieh, K., Chu, H.T., Mueller, K., Chan, Y.C., Rubin, C., Yeats, R., Chen, W.S., 2001. A vertical exposure of the 1999 surface rupture of the Chelungpu fault at Wufeng, Western Taiwan. Structural and paleoseismic implications for an active thrust fault. Bulletin of Seismological Society of America 91(5), 914-929.

Lee, J.C., Chu, H.T., Angelier, J., Chan, Y.C., Hu, J.C., Lu, C.Y., Rau, R.J., 2002. Geometry and structure of northern surface ruptures of the $1999 \mathrm{Mw}=7.6 \mathrm{Chi}-\mathrm{Chi}$, Taiwan earthquake: influence from inherited fold belt structures. Journal of Structural Geology 24(1), 173-192.

Lee, Y.H., Lu, S.T., Shih, T.S., Wu, W.Y., 2003. Comment on 'A vertical exposure of the 1999 surface rupture of the Chelungpu fault at Wufeng, Western Taiwan: structural and paleoseismic implications for an active thrust fault' by J.C. Lee et al. Bulletin of Seismological Society of America 93(2), 963-968.
Ma, K.F., Lee, C.T., Tsai, Y.B., Shin, T.C., Mori, J., 1999. The Chi-Chi, Taiwan earthquake: large surface displacements on an inland thrust fault. EOS Transactions 80(50), 605-611.

Mouthereau, F., Angelier, J., Lee, J.C., 2001. Le seisme du 21 septembre 1999: influence de l'heritage structural et implication du socle au front de la chaine de Taiwan. Compte Rendu Academy de Science Paris, v. serie IIa 333(1), 93-103.

Woodward, N., Boyer, S., Suppe, J., 1989. Balanced geological crosssections: an essential technique in geological research and exploration, 28th International Geological Congress, Washington, DC, pp. 132.

Yang, M., Rau, R.-J., Yu, J.-Y., Yu, T.-T., 2000. Geodetically observed surface displacements of the $1999 \mathrm{Chi}-\mathrm{Chi}$, Taiwan, earthquake. Earth Planets Space 52, 403-413.

Yu, S.B., Kuo, L.-C., Hsu, Y.-J., Su, H.-H., Liu, C.-C., Hou, C.-S., Lee, J.F., Lai, C.-C.L., Liu, C.-L., Tseng, T.-F., Tsai, C.-S., Shin, T.-C., 2001. Preseismic deformation and coseismic displacements associated with the 1999 Chi-Chi, Taiwan, earthquake. Bulletin of Seismological Society of America 91(5), 995-1012. 